\title{
Planning Sustainable Partnerships for Entrepreneurial Ventures in Professional Service Firms (PSFs)
}

\author{
Alaa Rady \\ IE Business School, Madrid, Spain \\ Luis J. Sanz \\ INCAE Business School, Managua, Nicaragua
}

\begin{abstract}
This paper starts by providing extensive literature review on entrepreneurship, starting from how to define it, to its macro-economical impact, to the different stages of entrepreneurial start-ups. The literature goes further in the resources needed to make such entrepreneurial ventures successful, and analyzes different agency problems that can arise between the entrepreneur and other financial investors. The paper is based on two case studies of new ventures in professional service firms (PSFs) analyzing the partnership mechanisms between the entrepreneur and other financial investors, highlighting potential problems that arise in real life, how to mitigate them. One of the case studies had the luck of fixing such partnership, leading to the satisfaction of all stakeholders and the creation of a sustainable entrepreneurial venture, while the other case study faced similar problems leading it to bankruptcy.
\end{abstract}

Keywords: entrepreneurship, entrepreneur, case studies, professional service firms, sweat equity, shadow equity, resources, conflict of interest, financial investors, MENA region

\section{Theoretical Foundation}

\section{Defining Entrepreneurship}

Entrepreneurship is defined in a many different ways within academic literature. Different schools emerged having different definitions (Cunningham, Barton, \& Lischeron, 1991) like the "great person school" focusing on intuitive entrepreneurs within start-up situations; the "psychological characteristics school" focusing on the entrepreneurs' values, attitudes and needs within start-up situations; the "classical school" focusing on innovation within start-ups and early growth situations; the "management school" defining entrepreneurs as organizers of an economic ventures, who organize, own, manage, and assume the risk within early growth and maturity ventures; the "leadership school" defining entrepreneurs as leaders mobilizing others within early growth and maturity ventures; and finally the "intrapreneurship school" defining entrepreneurship as the development of independent units to create, market and expand services within mature ventures. Some academic

\footnotetext{
Alaa Rady, Doctorate of Business Administration Candidate, IE Business School. Luis J. Sanz, Ph.D., University of Pennsylvania, M.E.E., Director of Entrepreneurship, INCAE Business School. Correspondence concerning this article should be addressed to Alaa Rady, IE Business School, Calle María de Molina, 11, Madrid 28006, Spain. E-mail: alaa.rady@yahoo.fr.
} 
work tries to shift the unit of analysis from the individual level to the functional level (Gartner, 1989) defining it as "entrepreneurship is the creation of new organizations"; while some later research disagrees (McKenzie, Ugbah, \& Smothers, 2007) trying to combine the latter definition with others and results in the following definition "entrepreneurship involves individuals and groups of individuals seeking and exploiting economic opportunity”.

Trying to take a different angle of defining entrepreneurship (Ireland, Reutzel, \& Webb, 2005) the authors analyze academic papers published on the topic in AMJ and what they focused on whether it was the individual or the venture, whether it focused on small businesses, new ventures, corporate entrepreneurship, as well as the predominant research methodologies used within such academic work. One of the contributions of the paper is that it highlights how academic work on entrepreneurship, which is all rather recent, has grown recently and evolved over the past few years in terms of focus subjects and methodologies used, and the research can predict somehow where it is going.

Last but not least, the largest piece of research ever conducted on entrepreneurship is the GEM report (Bosma \& Hardings, 2009), depicting an outstanding global effort, gathering data from 54 countries, conducting yearly interviews that amounted to 180,000 in 2009. The GEM report defines an entrepreneur as someone who embarks on a new venture for a minimum of three months, paying salaries (as a sign of commitment), and up to 42 months when he becomes owner-manager of an established business. The authors believe this definition, which is very close to the concept of "new start-ups" depicted already in the VC industry and well covered in different research within the finance arena, will prevail as the main definition going forward in future research; not because of its superiority in quality, or its closeness or relatedness to other scholars' opinions; but rather because of the size of the global database built by the research, that will serve as basis to so many other scholars in their future work on entrepreneurship.

For the purpose of this study, the authors will define entrepreneurship, as the start-up of a new venture, and early stage expansion (characterized by a large growth of around 25\% PA or more).

\section{Macro-economical Impact}

Whether entrepreneurship has an effect on the economical development of nations has been a myth that puzzled academics, and was one of the motivating factors behind the development of the GEM report (Bosma \& Hardings, 2009). This myth has been one of the driving forces behind several government initiatives and investments directed towards entrepreneurship, targeting economic growth.

Following up the development of the report since inception in 1999, the general belief that entrepreneurship is one of the driving factors behind economic growth, has been filtered down to a sub-set of countries characterized by their ability to produce "unique goods and services that are created via sophisticated, and often pioneering, methods" defining them as "innovation driven economies". The report implicitly admits that the observed relationship between economic growth and entrepreneurship could have a reverse causality, and is moderated by so many other factors, like government incentives, the level of un-employment... Further research (Van Stel, Carree, \& Thurik, 2005) establishes the same relationship between entrepreneurship and economic growth, but it also fails to establish the causality direction. Other findings of the research suggest the reverse causality of economic growth driving entrepreneurship, like the relationship between GDP per capital and the 
level of entrepreneurship for a sample of 36 countries.

\section{Entrepreneurial Process}

(1) Pre-entrepreneurship

In order to provide an academic framework to potential entrepreneurs, research explores several topics like soft and hard skills that are associated with successful entrepreneurs. Most of the research conducted in this area is based on case study analysis following an inductive approach, which the authors think, is the best methodology to follow for such a nascent, and broad (as we have seen from the different definitions) and intangible topic.

We believe that some of the academic work in that area is useful as it provides some empirical evidence or case study findings to potential entrepreneurs to think about. Examples of such work is A garage and an idea. What more does an entrepreneur need? (Audia \& Rider, 2005), which trying to clear the myth about high tech US start-ups, and how unconventional they are, and unrealistic to think they dominate the entrepreneurship arena. The paper establishes the importance of prior experience in the life of every entrepreneur, recognizing four factors as key to the success of the future ventures being 1. Exposure to information and technology relating to the new venture 2. Cross functional learning that allows the entrepreneur to fulfill a broad number of roles that end up being crucial as he/she ventures on his own 3 . Contacts and network with other individuals who could become potential partners/employees within his/her new venture 4. Access to key resource providers like suppliers, customers and investors who could become key to the success of his/her venture later on. The paper highlights that the best companies to work for, to establish the above, would be young dynamic firms. One further contribution of the paper is that it establishes the relationship between the entrepreneur's prior industry experience and the new venture he ends up establishing (in 29 out of 32 cases observed during the study).

Other studies in the authors' opinion are more prescriptive in nature, as they summarize their recommendations to potential entrepreneurs into checklists to go through checking sure whether he/she is qualified to be an entrepreneur and whether his/her idea qualifies to be a new successful venture. For example, Stevenson and Gumpert (1985) provides such a framework to entrepreneurs to see whether they fit more as entrepreneurs or as corporate employees; while other papers try to establish a framework for potential entrepreneurs to think whether they are on the right track, with a good solid idea and structure before taking the leap of faith (Bhide, 1996).

Other papers establish the difference between "creation type" and "recognition type" entrepreneurship (Miller, 2007), highlighting the differences between creating a new product, technology, process from scratch; versus fulfilling an existing need before others do. Even though the authors believe that the difference between both types is very difficult to assert, such research has the benefit of showing the different processes needed to deal with different types of entrepreneurial endeavors (Alvarez \& Barney, 2007) regarding decision-making, business planning, and finance... We hope to see future research focusing more on the first type "creation entrepreneurship" as it has received less attention from scholars thus far.

Some research in this pre-entrepreneurship area focuses on how to spot the opportunities (Baron, 2006), or what the paper calls "connecting the dots”, or researchers call "the discipline of innovation” (Drucker, 1985). Both papers provide good examples of how to use prior knowledge, search techniques, both combined with alertness to spot potential opportunities. 
(2) Marshalling resources for start-ups and early stage growth

Moving one step further in the entrepreneurial process, research (Reuber \& Fischer, 2005) covers four case studies, highlighting how an entrepreneur needs to take stock of the resources needed to start-up his/her venture being: (a) human (e.g., education, experience, industry knowledge, technical capabilities, and reputation); (b) social (network within potential stakeholders); (c) physical (e.g., machinery, trucks and office space); (d) Financial; (e) technological (e.g., patents); and (f) organizational (e.g., team). The paper shows that it is not necessary to have all above resources available in-house at the start of the new venture, as some of them can be outsourced and some can be bought externally rather than made internally which would require much more time and money. One of the implicit contributions of the paper is the comparison between a start-up venture situation, and an early stage one, both involving the same venture (Palm Computing later called Handspring). The paper briefly talks about how an entrepreneur could transform his personal resources into the new corporation, which is the area the authors decide to focus on within this paper.

(3) Personal resources of an entrepreneur necessary for the new venture

Previous studies (Brush, Greene, \& Hart, 2001) recognize human capital (e.g., reputation) and social capital (e.g., network) as among the most important factors an entrepreneur needs at the start of his/her new venture in the specific examples he drew within his case studies.

The other four types of resources were externally sourced in his case study examples. Financial resources were sourced through VCs, while the other three resources (physical, technological and organizational) were built up over time.

Other papers recognize reputation as one of the most important resources to build initially for a new venture (Reuber \& Fischer, 2005; Greenwood, Li, \& Deephouse, 2005) especially in professional service firms (PSFs) defined as businesses that deal with the dissemination of technical information such as consultancy firms, accounting firms and law firms. This reputation is built through the entrepreneur's ability to network (Shaw, Lam, \& Carter , 2008; Granovetter, 1985; Burt, 1997). Shaw recognizes in his paper several critical resources for the entrepreneur to transfer to the firm. Those according to him would be: (a) human capital (education, age, and experience); (b) social capital (network morphology and interaction); and (c) symbolic capital (the value others place on their human and social capital) (Burt, 1997). Taking a deeper look at social networks, Granovetter (1973) argue that "weak ties" of people who do not know each other well and have few contacts in common are more effective than "strong ties" of people knowing each other very well but sharing the same social circle. The reason he associated for that is the larger reach of "weak ties" to spread news, information (and advertise for a new venture in one's own context).

For the sake of the study, the authors decide to use Brush's six resources (Brush, Greene, \& Hart, 2001) to depict some of the potential resources that an entrepreneur could add into his new venture. Those six resources are: (a) human; (b) social; (c) physical; (d) financial; (e) technological; and (f) organizational. Based on other research findings below, the authors recognize that the first two resources are the most commonly transferred from an entrepreneur to his new venture, especially for PSFs, being the same set-up that we will use for the sake of this case study. However we recognize the need for every entrepreneur to define his/her own set of critical resources needed within his/her firm, making a stock of what he/she possesses already versus other resources needed critically at the start-up phase that he/she should buy/outsource externally. 
(4) Agency problems and entrepreneurs remuneration

Researchers' (Fama \& Jensen, 1983) paper explains how different agency problems may arise between managers and owners, when decisions (by managers) are separated from risk taking (by financial investors). The case arises in new entrepreneurial projects when entrepreneurs are not properly remunerated as managers, separating their role as managers from their role as investors, as they need to be remunerated as stand-alone managers as if an external manager were to be recruited. Another agency problem arises when entrepreneurs as managers are given total free hand to manage the company as they like, pushing their own agendas as managers and owners over the rights of other financial investors. The authors believe the issue to be linked to the first one, being the proper remuneration of entrepreneurs as managers.

Further research (Fama, 1980) explains that an entrepreneur bears more responsibilities than other shareholders in a firm, management and risk bearing.

The normal remuneration that would keep the balance is according to the paper an ex-post settling up package that integrates the true price of the entrepreneur if he were to do a normal job in a different company; otherwise that would lead the entrepreneur to dissatisfaction. Benjamin and Margulis' (2000) book explains other remuneration techniques to entrepreneurs including sweat equity as being free equity given to the entrepreneur to compensate him for the extra risk and management he takes over and above other financial investors, especially in service firms. The case becomes more clear when the entrepreneur gets a below market salary at the start-up years not to over-burden the company with high salaries in the beginning. Another form of compensation is shadow equity, which is equity the entrepreneur gets without paying it, that becomes a due on the entrepreneur to be paid later on from his dividends from the company.

\section{Case Studies}

The authors use two case-studies, as an inductive approach in this research, as already explained the appropriateness of using such methodology in a new emerging intangible research area being "entrepreneurship". Yin (1994) suggests that case study research focuses more on the "how" and the "why" and is suitable to study complex social phenomena like the paper at hand.

\section{Financial Services Company (EFS)}

Case study 1 covers EFS is a boutique PSF that started in 2007, doing investment banking and strategy consulting firm with headquarters in Cairo, Egypt and covering the MENA region in terms of clients and M\&A projects implemented. As other service companies the capital needed to start the company were modest. The initial paid-in capital of the company was 30K US\$, that was brought up to 120K US\$ at the end of the first fiscal year, and shared among five partners in different percentages. Only two among the partners decided to leave their full time jobs and lead the start-up at its initial stages with very modest salaries, with an understanding that two other partners will join full-time at a later stage once the company is large enough to accommodate them. The other three non-operating partners were supposed to help introduce new potential clients, one of the three non-operating partners ended up being moderately effective, the other two partners not effective at all (summary of the situation below).

The first year of operation was successful in terms of attracting new clients, based on the contact list and reputation of partners 1-2-3 and the efforts and full-time work of partners 1 and 3 . The second and third years 
depicted major differences in value-added among the partners as partner 1 ended up generating $90 \%$ of the company's revenues, leading the company to an initial success as a start-up. Then conflict arose among the partners, with several layers of complexity.

- Partners 1-2-3 formed an alliance, wanting to dilute partners 4-5 since the latter were exerting no effort in the company, and did not join as full-time operating partners as promised, and indeed they bought out their shares at 5-6 times the initial investment after two years of the initial investment;

- Partners 1 and 3 formed an alliance, wanting to be the ones to buy the shares of partners 4-5 to increase their stake as the only two managing partners, and wanting to adjust their salaries to a market level. Partner 2 accepted, so it was done successfully;

- Partner 1 wanted to introduce a variable part of the pay to depict the work exerted in bringing in new clients to EFS and closing deals, which the other two partners accepted.

So the company continued its operations with a new adjusted level of salaries and ownership as described below.

\section{Orion-Intercap (OI)}

The second case study depicts a company that started operations in Egypt in 2006 covering the MENA region as well for M\&A advisory only, with an initial paid-up capital of 200K US\$, half of which was raised on the spot and the rest was called upon after one year. The partners were a couple of entrepreneurs from Egypt, a financial institution (FI) from the GCC, and another one from Syria. The partnership initial value added was expected to be that both Egyptians partners work full-time on the venture, establishing the main office in Cairo, recruiting analysts, training them and conducting business with the help of both financial institutions sending them regional business, to be conducted from Egypt as ground-work and travelling back and forth to meet clients, and fulfil the regional mandates. Table 1 explains the situation in a clearer format.

Table 1

Case Study 2-OI

\begin{tabular}{lllllc}
\hline & $\begin{array}{l}\text { Initial } \\
\text { investment }\end{array}$ & $\begin{array}{l}\text { Total } \\
\text { investment }\end{array}$ & Full-time work at OI Help introducing new clients & $\begin{array}{l}\text { Ownership } \\
(\%)\end{array}$ \\
\hline Partner 1 & 10K US\$ & 20K US\$ & Below market salary Yes in Egypt & 10 \\
Partner 2 & 15K US\$ & 30K US\$ & No salary & Yes in Egypt & 15 \\
FI from GCC & 50K US\$ & 100K US\$ & No & Yes, but no resources to fulfil mandates & 50 \\
FI from Syria & 25K US\$ & 50K US\$ & No & Yes, but no resources to fulfil mandates & 25 \\
\hline Total & 100K US\$ & 200K US\$ & & & 100 \\
\hline
\end{tabular}

The issues arose when Partner 2 ended up leaving the business after six months joining a PE fund (as shown in Table 1) keeping his salary the same, and throwing all the business on Partner 1, who was taking no salary (only withdrawing money in advance to be balanced with his bonus at the end of every year). Moreover, the company was not properly capitalized leading the team to be very slim, and not able to fulfil any regional business, and thus not really capitalizing on the partnership with the two regional FI from GCC and from Syria. So Partner 1 ended up leading all the work with no salary, sweat or shadow equity to compensate for his full-time involvement, and as the company was not properly capitalized, he could not even recruit a decent team to fulfil the needed work for the mandates. 
Partner 1 tried to initiate some changes by buying the shares of the others at face value as the company did not generate any superior returns or any profits, but Partner 2 refused. The two partners kept fighting each other, and lobbying with the other partners to push their own agenda, knowing that the two institutions were large in size, and not having the time to bother about such a small failed start-up so had no reactions and did not attend any of the board meetings. Unlike case study 1, the company ended up filing for bankruptcy and closing shop.

\section{Discussion}

The authors would like to bring several topics discussed in this paper into light through the case study at hand.

\section{Personal Resources of Entrepreneurs Important to the New Venture and How to Weigh Them}

As discussed in the theoretical foundation, there are six types of resources important to a new venture: (1) human; (2) social; (3) physical; (4) financial; (5) etechnological; and (6) organizational. In the first case study EFS, the most important resources at the start-up were the human and social ones, as the company needed full-time partners to work and put the venture together, as well as introduce new potential clients to the venture based on the personal reputation and social network of the partners as the venture did not have any track record, yet to build upon. Following in importance were financial resources needed to invest in the venture, that were very modest compared to the net worth of the different partners taking part of the new venture. Following in importance were organizational resources that were put together over the time. Last in importance were physical resources, as the company was only renting an office, and bought some office furniture, computers... Technological resources were not relevant to EFS. In the second case study (OI) the same priority for success was the human and social value added from the different partners to bring in business, but as the company did not close any immediate mandates, it needed to be capitalized more properly to be able to build a team to fulfil the work sent by the different partners, knowing that it was not a huge amount of money requested.

The authors argue in this paper that the initial weighing of the resources was not conducted properly between the different partners in case study 1 , and thus the partnership structure ended up (see Table 2) not reflecting the real work and was only based on the financial resources invested in the company while financial resources were not the most important key success factor to the new venture for case study 1 . That in turn led to a conflict among the partners。

Table 2

Case Study 1-EFS Initial Company Structure

\begin{tabular}{lllllr}
\hline & $\begin{array}{l}\text { Initial money } \\
\text { invested }\end{array}$ & $\begin{array}{l}\text { Total investment } \\
\text { (including 2nd portion) }\end{array}$ & Full-time work at EFS & $\begin{array}{l}\text { Help introducing } \\
\text { new clients }\end{array}$ & Ownership (\%) \\
\hline Partner 1 & 9K US\$ & 36K US\$ & Yes at modest salary & Very effective & 30 \\
Partner 2 & 9K US\$ & 36K US\$ & No & Moderately effective & 30 \\
Partner 3 & 6K US\$ & 24K US\$ & Yes at modest salary & Little effective & 20 \\
Partner 4 & 3K US\$ & 12K US\$ & Promised to join after 1 year & Not effective & 10 \\
Partner 5 & 3K US\$ & 12K US\$ & Promised to join after 1 year & Not effective & 10 \\
\hline Total & 30K US\$ & 120K US\$ & & & 100 \\
\hline
\end{tabular}

The same issue arose in case study 2 as Partner 1 who ended up carrying all the work only help $10 \%$ of the company not giving him enough incentive to carry on all the work on its own. 


\section{Border-Line Between the Entrepreneur and the New Venture}

A new venture with different partners in fact is different than the entrepreneur. The presence of different partners makes way to agency problems. The authors argue in this paper that agency problems should be identified at the start of every such partnership, and different governance mechanisms put in place to make sure the best interest of all stakeholders is protected. In the case of EFS, partners 1 and 3 played a dual role as managers and partners. The initial partnership structure in Table 1, did not reflect that, and only considered them as partners, which led to their frustration towards other partners. Upon discussion with partner 2, the proper remuneration was incorporated into their packages through a fixed pay to reflect their work as managers. The same exact problem arose in the second case study OI, as Partner 1was not properly remunerated as a manager through a salary, bonus, free equity... neither was Partner 2 who left only after six months.

A further governance issue took place in EFS, being the business generation not being remunerated in phase 1 (see Table 2), which led to the frustration of partner 1, leading to the introduction of the variable pay (see Table 3), to ally the interest of the three partners with the interest of the new venture, so they would all three exert effort in bringing in new clients to the EFS (see Table 3).

Table 3

Case Study 1-EFS Adjusted Company Structure

\begin{tabular}{llllc}
\hline & Full-time work at EFS & Help introducing new clients & Variable pay & Ownership (\%) \\
\hline Partner 1 & Yes at market salary & Very effective & Very high & 40 \\
Partner 2 & No & Moderately effective & Medium & 30 \\
Partner 3 & Yes at market salary & Little effective & Low & 30 \\
\hline Total & & & 100 \\
\hline
\end{tabular}

\section{Mechanisms of Transferring the Resources of the Entrepreneur to the New Venture}

A new venture that continues after 2-3 years to solely depend on the entrepreneur to bring in new business, have the clients contacts, business databases, is not a sustainable one. A part of the salary the venture (owned by other stakeholders as well) pays by the entrepreneur is to transfer his know-how, contact list, soft and hard skills into the other employees of the new venture, and training them, to insure the sustainability of the new venture. This mechanism needs to be watched by the shareholders in such a new venture, otherwise the new venture ends up worth nothing without the entrepreneur who holds all the strings in his hands. Assuming the entrepreneur leaves the company upon conflict, and starts another similar PSF called "EFS 2" for the sake of argument, all the business will be transferred from "EFS" to "EFS 2", while the other shareholders of EFS would have invested their money for nothing.

Case study 2 highlighted this problem more clearly as Partners 1 and 2 both ended up leaving the venture, and each started their own boutique investment banks, taking away the clients from OI who filed for bankruptcy.

\section{Conclusions and Limitations}

As a conclusion from the two case studies analyzed, new entrepreneurial ventures need to be structured in the beginning bearing in mind that the main input that goes into the company is the time and effort of the 
entrepreneur in the case of PSF where the initial capital invested in not that meaningful and the key success factors of the venture lie more in the social and human capital of the entrepreneurs/managers. Accordingly those entrepreneur/managers need to be properly remunerated (market salaries) for their job as managers and the risk they undertake working on such start-ups versus building their career in a safer environment within larger organizations. Such market salaries can be mitigated by other forms of remuneration like sweat equity or shadow equity. On the other hand, agency problems need to be considered separating management from ownership from the beginning to protect both sides (entrepreneurs versus financial investors), and the entrepreneur needs to transfer his human and social capital into the new venture to ensure the sustainability of the organization going forward (and not to depend solely on the entrepreneur).

The paper relies on case study research, studying two cases from the MENA region, both being PSFs with a low level of capital investment needed in the beginning. One of the limitations of using case study research is the difficulty of generalizing the results to other settings (Eisenhardt, 1989). The authors believe that the results are relevant to other geographies, but the authors recognize the limitation of the results to PSF firms. Larger start-ups like industrial ones, have other key success factors like the financial capital as very important, decreasing the importance of the human and social capital of the entrepreneur. In the latter case, sweat and shadow equity forms of remuneration become less important to compensate the entrepreneur for earning less than market salaries, as the ventures can afford market salaries, and become more relevant for motivational purposes to align the objectives of the entrepreneur as manager with the objective of other stakeholders (financial investors), and can be replaced by variable pay linked to performance over and above market salaries.

For future research, the authors recommend more qualitative work to follow to clarify further how provide further insights on how partnerships can and should be structured for new entrepreneurial ventures, in different setups. Such work can be followed by quantitative work to provide decent number of findings to reinforce the conclusions and increase the reliability of such work.

\section{References}

Alvarez, S. A., \& Barney, J. B. (2007). Discovery and creation: Alternative theories of entrepreneurial action. Strategic Entrepreneurship Journal, 1, 11-26.

Audia, P., \& Rider, C. (2005). A garage and an idea. What more do an entrepreneur need? California Management Review, 48(1), 6-28.

Baron, R. (2006). Opportunity recognition as pattern recognition: How entrepreneurs “connect the dots” to identify new business opportunities. Academy of Management Perspectives, 20(1), 104-119.

Benjamin, G. A., \& Margulis, J. B. (2000). Angel financing: How to find and invest in private equity. New York: Wiley.

Bhide, A. (1996). The question every entrepreneur must answer. Harvard Business Review.

Bosma, N., \& Hardings, R. (2009). GEM global report. Retrieved from http://www.gemconsortium.org/

Brush, C., Greene, P., \& Hart, M. (2001). From initial idea to unique advantage: The entrepreneurial challenge of constructing a resource base. Academy of Management Executive, 15(1), 64-80.

Burt, R. (1997). The contingent Value of social capital. Administrative Science Quarterly, 42, 339-365.

Cunningham, J. B., \& Lischeron, J. (1991). Defining entrepreneurship. Journal of Small Business Management, $29(1), 45-61$.

Drucker, P. (1985). The discipline of innovation. Harvard Business Review, 63(3),67-72.

Eisenhardt, K. (1989). Building theories from case study research. Academy of Management Review, 14, in press.

Fama, E. F.(1980). Agency problems and the theory of the firm. Journal of Political Economy, 88(2), 288-307.

Fama, E. F., \& Jensen, M. C. (1983). Separation of ownership and control. The Journal of Law and Economics,26(2), 301-325.

Gartner, W. (1989). Who is an entrepreneur? Is the wrong question. Entrepreneurship: Theory and Practice, 13(4), 47-68. 
Granovetter, M. (1973). The strength of weak ties. American Journal of Sociology, 78, 1360-1380.

Granovetter, M. (1985). Economic action and social structure: The problem of embeddedness. American Journal of Sociology, 91, 481-510.

Greenwood, R., Li, S. X., \& Deephouse, D. L. (2005). Reputation, diversification, and organizational explanations of performance in professional service firms. Organization Science, 16(6), 661-673.

Ireland, D., Reutzel, C., \& Webb, J. (2005). Entrepreneurship research in the AMJ: What has been published, and what might the future hold? Academy of Management Journal, 48(4), 556-578.

McKenzie, B., Ugbah, S. D., \& Smothers, N. (2007). Who is an entrepreneur? Is it still the wrong question? Academy of Entrepreneurship Journal, 13(1), 23-43.

Miller, K. D. (2007). Risk and rationality in entrepreneurial processes, strategic. Entrepreneurship Journal, 1, 57-74.

Reuber, R., \& Fischer, E. (2005). The company you keep: How young firms in different competitive contexts signal reputation through their customers. Baylor University.

Shaw, E., Lam, W., \& Carter, S. (2008). The role of entrepreneurial capital in building service reputation. The Service Industries Journal, 28(7), 899-917.

Stevenson, H., \& Gumpert, D. (1985). The heart of entrepreneurship. Harvard Business Review, 63(2), 85-94.

Van Stel, A., Carree, M., \& Thurik, R. (2005). The effect of entrepreneurial activity on national economic growth. Small Business Economics, 24(3), 311-321.

Yin, R. K. (1984). Case study research, design and methods. California: Sage Publications, Beverly Hills. 